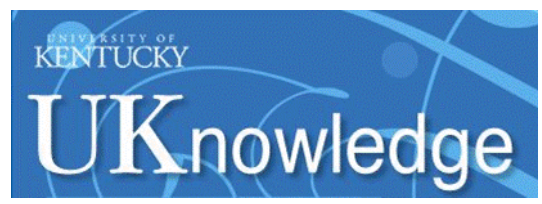

Kentucky Journal of Equine, Agriculture, \& Natural Resources Law

\title{
Community Supported Agriculture: How Do Maryland Operators Manage Legal Risks?
}

\author{
Paul Goeringer \\ University of Maryland \\ Mayhah Suri \\ University of Maryland
}

Follow this and additional works at: https://uknowledge.uky.edu/kjeanrl

Part of the Agriculture Law Commons

Right click to open a feedback form in a new tab to let us know how this document benefits you.

\section{Recommended Citation}

Goeringer, Paul and Suri, Mayhah (2016) "Community Supported Agriculture: How Do Maryland Operators Manage Legal Risks?," Kentucky Journal of Equine, Agriculture, \& Natural Resources Law. Vol. 9: Iss. 2, Article 3.

Available at: https://uknowledge.uky.edu/kjeanrl/vol9/iss2/3

This Article is brought to you for free and open access by the Law Journals at UKnowledge. It has been accepted for inclusion in Kentucky Journal of Equine, Agriculture, \& Natural Resources Law by an authorized editor of UKnowledge. For more information, please contact UKnowledge@lsv.uky.edu. 


\title{
CoMmunity Supported Agriculture: How Do Maryland Operators Manage Legal RISKS?
}

\author{
Paul Goeringer \& Mayhah Suri*
}

\section{INTRODUCTION}

Many people interested in strengthening the connection between land, food, producer, and consumer have embraced community-supported agriculture ("CSA"), an alternative farming system increasingly popular in the United States. The CSA model was introduced in the United States by two Northeastern farms in 1986. ${ }^{1}$ Since then, CSA popularity has exploded, with over 12,500 CSA farms nationally, according to the 2012 Census of Agriculture. $^{2}$ The basic premise of the CSA model is that community members pledge support to a farm, and the farmer relies on this support instead of traditional financial venues. Though some farms accept volunteer labor, most CSA members purchase a share of the future produce at the beginning of the season. Members cover the farmers' operational costs and receive periodic shares of the farm's products, often vegetables and fruit.

The CSA model inverts the traditional agricultural model. Rather than relying on sales at the end of the season to recover costs, CSA farmers have the capital they need at the beginning of the season from selling CSA memberships. CSA farmers receive a steady stream of income, protecting them from the economic consequences of low yields. CSA members, in turn, receive part of the farm's bounty, usually weekly, and enjoy a connection to the land and the food they are consuming. ${ }^{3}$ Inherent to this model is the spreading of risk to consumers. In a conventional agricultural

* Paul Goeringer J.D., 2007, University of Oklahoma, LL.M. 2009, University of Arkansas, Extension Legal Specialist, Department of Agricultural and Resource Economics, College of Agriculture and Natural Resources, University of Maryland; Mayhah Suri, B.S. 2015, University of Maryland, Research Assistant, Agriculture Law Education Initiative, University of Maryland.

1 Cynthia Abbott Cone \& Andrea Myhre, Community-Supported Agriculture: A Sustainable Alternative to Industrial Agriculture?, 59 HUMAN ORG. 187 (2000), http://sfaajournals.net/doi/pdf/10.17730/humo.59.2.715203t206g2j153 [https://perma.ce/TD8H-EGKZ].

2 Nat'l Agric. Statistic Serv., 2014 Census of Agriculture 558 (USDA 2014).

${ }^{3}$ Cone \& Myhre, supra note 1 , at 187. 
system, consumers are protected from risk factors such as inclement weather, pest damage, and other causes of low yields due to the large scale. By investing in the farm's future bounty at the beginning of the season, the members are just as vulnerable as the farmers. If the crops fail, members may not see a return on their investment. 4

Concerns from CSA customers lead the Maryland Department of Agriculture ("MDA") to conduct an online survey of self-identified CSA farmers and members in the summer of 2014. Survey results showed an information gap between farmers and members arising from confusing membership agreements and lack of written explanations. These results, lead MDA to cooperate with extension researchers at the University of Maryland to develop better contracts and other resources to continue strong CSA growth in the state.

This article will examine and compare some of the methodologies and results of CSA programs around the United States. Section II will look at California's recent law that regulates what is considered a CSA and will evaluate voluntary state marketing programs, like Kentucky's Kentucky Proud program, and how those programs could impact CSAs elsewhere. Section III.A will look at the methodology of how the surveys were conducted to determine in which CSA operators managed risk in their operations. CSA members' perceptions on agreements were separately surveyed as well. Section III.B will highlight the results found in the two surveys. Section IV discusses the materials that developed out of the research conducted by the MDA. Finally, Section V will highlight the next steps in educating operators on better strategies to manage legal risks in CSAs.

\section{CURRENT LAWS IMPACTING CSAS}

Nationwide, CSA operators often forgo the use of written contracts. ${ }^{5}$ As one author has highlighted, many operators have

${ }^{4}$ Nicholas R. Johnson et al., Community Supported Agriculture: An Exploration of Legal Issues and Risk Management Strategies, 28 NAT. RES. \& ENV'T. (2013), https://tnlocalfood.files.wordpress.com/2015/12/johnson-et-al-csas-legal-issues.pdf [https://perma.cc/V9WB-SZVV].

${ }^{5}$ See id. at 2. 
left corporate America and do not want to use written agreements. ${ }^{6}$ Currently, the majority of states have not adopted laws that relate only to CSAs. Although few states have adopted CSA-specific laws, CSAs will still need to comply with state contract laws, food safety, and other general laws impacting all food operators.

\section{A. Mandatory State Law Programs}

California is currently the only state with a specific statutory scheme related to CSA operators. ${ }^{7}$ The goal of California's program was to create a precise definition of who can and cannot call themselves a "CSA" and relatedly, who can and cannot reap the benefits associated with the CSA label. ${ }^{8}$ California legislators were motivated by complaints from CSA farmers who observed that large agribusinesses and cooperatives were incorrectly labeling their operations as "CSA farms". 9 This confused consumers and made it difficult for true CSA farmers to compete with the larger companies. Despite proclaiming to be locally produced, some companies were filling shares with tropical fruits not even grown in the United States, such as bananas. CSA farmers felt these larger agribusinesses were unfairly profiting by incorrectly marketing their products as CSA products. This type of complaint led to an interest in legislative action. ${ }^{10}$

The California program defines a CSA farm as either a single-farm operation or a multi-farm operation in which a registered direct marketing producer grows food for a group of California consumer shareholders or subscribers who pledge or

${ }^{6}$ See id. at 2.

${ }^{7}$ CAL. AGRIC. CODE $\S \S 47060-47062$ (West 2016).

8 Interview with Steve Patton, Branch Chief Inspection and Compliance, California Department of Food and Agriculture, in College Park, Md. (Oct. 8, 2015) [hereinafter Patton Interview].

${ }^{9}$ See id.

10 On the Heels of Farm-to-Fork Week, Gordon Bill Supporting Expansion of Community Supported Agriculture Signed by Governor Brown, Assemblyman Rich Gordon (2013), http://65.99.240.155/members/a24/news-room/press-releases/on-the-heelsof-farm-to-fork-week-gordon-bill-supporting-expansion-of-community-supportedagriculture-signed-by-governor-brown (last visited Jan. 27, 2017) [https://perma.cc/Y96KFXAG]. 
contract to buy a portion of the producer's future bounty. ${ }^{11}$ The farmer, or farmers, must register with the state agriculture department, helping to eliminate operations using the CSA label incorrectly. There are other requirements for California farmers, such as an annual registration fee and labeling requirements designed to improve transparency between farmers and members. ${ }^{12}$ The farmer must inform the consumers, either through their website (if they have one) or in the share boxes, who produced which items. ${ }^{13}$ For example, if a farmer produced all the fruits in the share but purchased the honey, the law requires farmers to indicate which farm the honey was purchased from. ${ }^{14}$

Essentially, the law gives a concrete definition to the term "CSA farm". Producers running cooperatives or distribution-type operations can no longer use the term "CSA" for marketing purposes. ${ }^{15}$ This program, which began in January 2014, has been mostly well-received. ${ }^{16}$ Farmers expressed hesitation at the annual cost but were generally happy to have a law backing up the meaning of a CSA farm. ${ }^{17}$

\section{B. Voluntary State Law Programs}

Many state departments of agriculture offer state marketing programs for products grown in that state. These state marketing programs, such as Kentucky Proud, provide state consumers assurances that the commodities they purchase are produced in Kentucky. These statewide agriculture marketing programs could also be utilized to offer customers guarantees that the products bought are grown in the state.

According to its website, "Kentucky Proud stands for foods, nursery items, crafts, agritourism sites, farmers' markets, state parks, and many other products and destinations with roots

\footnotetext{
${ }^{11}$ CAL. AGRIC. CODE $\$ 47060(b)-(c)$ (West 2016).

12 Id. $\$ 47061$.

${ }^{13}$ Id. $\$ 47061(\mathrm{a})(4)$.

14 See id.

${ }^{15} I d . \S 47060(a)$.

16 Patton Interview, supra note 8.

${ }^{17}$ See id.
} 
in Kentucky soil."18 The goal is to provide consumers with a tool to purchase food products that "are raised, grown, or processed in Kentucky by Kentuckians." 19 This program currently may not offer assurances to Kentuckians that CSA operators are utilizing explicit membership agreements.

With Kentucky Proud, eligible applicants must follow the requirements of the Kentucky Department of Agriculture. In reviewing the application, the product's primary ingredients must be grown in Kentucky, the farms, processing facility, or corporate headquarters must be located in Kentucky, and the facility needs to meet all applicable state and federal laws. Kentucky Proud and other state marketing programs could operate similarly to California's CSA program by providing assurances that the CSA is delivering products grown in the state. The differences are that California's program is required for any CSA operator to enroll in to use the term "CSA" in the state, whereas Kentucky's program is voluntary, and there is no similar requirement that all CSA operators register in Kentucky before marketing a CSA.

\section{Problems with Existing State Laws}

Currently, state laws impacting CSAs are limited to ensuring that the CSA label is being used correctly (California's law) or voluntary programs ensuring products are grown in the state (Kentucky Proud). These laws do not address the issue of having CSA operators explain risks to members. Neither the California law nor Kentucky's marketing program require CSA operators to use fully developed membership agreements to explain risks to members.

As will be discussed, this project was designed to fill the gap that current state laws do not address, assisting CSA operators in developing membership agreements, which explain the potential risks to CSA members. These educational materials can help CSA operators and members better understand the risks and what to look for in a good membership agreement.

18 Why Buy Kentucky Proud?, KenTUCKY PROUD (last visited Feb. 1, 2017), http://www.kyproud.com/why-buy-ky-proud.html.

${ }^{19}$ Id. 


\section{SURVEY METHODOLOGY AND RESULTS}

\section{A. Methodology}

In the summer of 2014 , two surveys were written, one for CSA farm owners and one for CSA farm members. The questions covered a range of topics such as marketing strategies, types of produce sold and bought, acreage, and risk communication strategies. The surveys were written and distributed using Qualtrics, Inc., an online survey builder and distributor.

Links to the surveys were distributed via individual emails. The email sent to the farmers included a brief description and a link to the member survey. The MDA asked farmers to forward the link to their past and current members in order to respect privacy considerations. When the survey was closed after a few weeks, a total of thirty-two farmers and sixty-eight CSA farm members had responded.

While analyzing survey results, special attention was given to responses regarding risk communication and member experiences with CSA farms. After noticing inconsistencies in farmer and member answers about risk communication, membership agreements and contracts publicly available online were reviewed to assess how farmers described risk.

\section{B. Results}

The surveys contained a variety of questions designed to help the MDA understand Maryland's CSA farms. In the questions pertaining to risk management, a few notable discoveries were made:

- Of the farmers who responded, 68 percent said they already use some type of membership agreement or contract.

- Some 70 percent of farmers answered that they specifically mentioned the risk of lowered yields, either in the agreement or verbally.

- Despite the farmers' efforts, only 33 percent of consumers responded they specifically learned about risk. 
That is, even though 70 percent of farmers reported efforts to communicate risk, 67 percent of consumers did not hear about risk, did not remember, or did not fully understand what was communicated. Given this gap, University of Maryland decided to look into the CSA contracts farmers are using. After analyzing twenty-two CSA contracts from Maryland farms available online, the University of Maryland found that the risk explanation portions of contracts currently in use were vague, confusing, and in some cases absent. ${ }^{20}$

\section{MATERIALS DEVELOPED}

To help Maryland CSA farmers develop clearer risk communication tools, a model contract was developed. It is based on the contracts CSA farmers already use, and includes space for farmers to personalize the document with their own details and information. In the model contract, the risk communication section is prominent and uses clear language to explain the risk of lowered yields. Accompanying the model contract is a contracting guide that walks farmers through each step of creating and using a contract, including tips related to protecting the farm. The guide includes a list of videos available covering a range of relevant topics, including information on contracts, labor, and crop insurance practices related to CSA farming.

Additionally, the University of Maryland conducted inperson workshops and webinars to provide farmers with detailed information on how to use membership agreements, the model contract, and accompanying guide. The resources and materials created for the workshops were published online to make them easily accessible. ${ }^{21}$ The materials from the webinars were also published online as videos. ${ }^{22}$ All materials can be found on the University of Maryland Extension website. ${ }^{23}$

wo This research was funded through a grant from USDA's Agricultural Marketing Service's Federal State Marketing Improvement Program in 2014.

${ }_{21}$ Dep't of Agric. \& Res. Econ., Community Supported Agriculture (CSA) Publications, UNIV. OF MD., http://go.umd.edu/CSAPage (last visited Jan. 27, 2017) [https://perma.ce/YU2W-77XB].

${ }^{22} I d$.

${ }^{23} I d$. 


\section{NEXT STEPS}

The survey and subsequent review of contracts pinpointed a clear problem area - poor communication between farmers and members. This issue may be solved with the new resources created through this program, such as the model contract and contracting guide. Before adopting a regulation scheme, it will be important to see if the new resources help to resolve the communication problem. A possible next step could be repeating part or all of the survey in a few years to assess implementation of membership agreements and the quality of risk communication methods. If consumer complaints persist, and perhaps to strengthen consumer confidence in the CSA farm system, an alternative to adopting a full regulatory scheme is to create a CSA farm certification program like that found in California. ${ }^{24}$

So what does this mean for Maryland or states like Kentucky? These states could consider adopting a registration or certification program using the California program as a model, rather than a more burdensome regulatory program. Certified farms could use a unique logo or display a certificate to signify meeting certain requirements. One such requirement for the certification process could be adopting requirements for CSA operators to explain risks of agriculture on their websites or in agreements themselves. This could even be a voluntary program, which would minimize regulation but still provide flexible yet firm standards.

\section{CONCLUSION}

Maryland CSA farmers are already trying to address risk communication. With the materials produced as a result of this project, CSA farmers now have resources to improve and develop their operations. There is insufficient evidence that a regulatory program of CSA farms is needed in Maryland. It will be important to monitor risk communication successes and failures now that farmers have more information about risk communications strategies, specifically the model contract. If 
issues continue, a definition-based program like the one in California may be a good alternative to more demanding regulation. Another option is a certification program, either mandatory or voluntary. CSA farming is an excellent way to encourage more consumers to buy local agricultural products and build strong relationships between farming and non-farming communities. With the right amount of support from government institutions and extension programs, CSA farms can continue to thrive and provide high quality produce to consumers looking for local agricultural products. 